\title{
KESIAPAN BERWIRAUSAHA MAHASISWA JURUSAN ILMU KESEJAHTERAAN KELUARGA FAKULTAS PARIWISATA DAN PERHOTELAN UNP
}

\section{Ngainul Mardiah ${ }^{1}$, Lucy Fridayati ${ }^{2}$}

${ }^{1}$ Dosen Pendidikan Kesejahteraan Keluarga, Universitas Negeri Padang

${ }^{2}$ Prodi Pendidikan Kesejahteraan Keluarga, Fakultas Pariwisata dan Perhotelan,

Universitas Negeri Padang

Jl. Prof. Hamka Kampus UNP Air Tawar Padang

Email: ngainulmardiah@gmail.com , lusifridayanti@fpp.unp.ac.id

\begin{abstract}
This research aims to describe and determine how entrepreneurial readiness of the Faculty of Tourism and Family Welfare Department of Padang State University. This type of research is a quantitative descriptive - The population of this research is the students Department of Family Welfare Education Study Program of family welfare berjumlah122 students. Sampling techniques using the proportional Random Sampling technique amounted to 55 students. The data collection technique is to disseminate the questionnaire (questionnaire) that has been proven validity and reliability. Further data is analyzed through descriptive analysis with the method of categorizing assessments based on average score and percentage assessment. The results showed that the respondents ' readiness for entrepreneurship of the Family Welfare Department students overall amounted to $56 \%$ in medium category. Further entrepreneurial readiness is reviewed from personality indicators of $51 \%$ by medium category, motivation indicator at $53 \%$ with medium category, personality indicator by $58 \%$ with medium category and knowledge indicator of $51 \%$ Medium category.

Keywords: readiness, entrepreneurial, entrepreneurship
\end{abstract}

\section{PENDAHULUAN}

Jurusan Ilmu Kesejahteraan Keluarga berada di bawah naungan Fakultas Pariwisata dan Perhotelan Universitas Negeri Padang. Jurusan Ilmu Kesejahteraan Keluarga memiliki satu Program Studi Kependidikan dan dua Program Studi Non Kependidikan. Program Studi tersebut adalah Pendidikan Kesejahteraan Keluarga (S1), Tata Boga (D3), dan Tata Busana (D3). Program Studi Pendidikan Kesejahteraan Keluarga memiliki 2 Konsentrasi, yaitu Konsentrasi Pendidikan Tata Boga dan Konsentrasi Pendidikan Tata Busana. Tujuan dari Jurusan Ilmu Kesejahteraan Keluarga tidak hanya menghasilkan lulusan sarjana dibidang pendidikan, tapi juga non kependidikan. Bidang non kependidikan ini salah satunya 

bekerja di industri tetapi juga bisa membuka usaha sendiri. Hal ini memungkinkan mahasiswa untuk bisa berwirausaha atau membuka usaha sendiri setelah lulus kuliah.

Untuk menunjang tujuan tersebut, mahasiswa Jurusan IKK khususnya Program Studi Pendidikan Tata Boga dibekali dengan beberapa mata kuliah.Mata kuliah tersebut dikelompokan menjadi beberapa bagian yang tersusun dalam kurikulum Pendidikan Kesejahteraan Keluarga (2015) diantaranya mata kuliah Kewirausahaan dengan bobot 3 SKS, mata kuliah Pengelolaan Usaha Boga (PUB) dengan bobot 3 SKS dan mata kuliah Restoran dan Katering dengan bobot 3 SKS.Mata kuliah tersebut berperan dalam melatih mahasiswa untuk mendalami teori tentang berwirausaha dan pengaplikasian berwirausaha secara langsung.

Berbekal tiga mata kuliah tersebut, mahasiswa diharapkan setelah perkuliahan mampu untuk mengaplikasikan pembelajarannya. Mahasiswa dapat mengaplikasikan dengan cara membuka usaha atau berwirausaha sendiri. Sehingga mahasiswa tidak hanya fokus untuk mejadi pendidik atau mencari pekerjaan lain, akan tetapi juga berkembang di bidang usaha terutama makanan. Sesuai tujuan dari Jurusan IKK adalah mampu bekerja sama dengan DUDI (Pedoman Akademik, 2015). Mahasiswa diharapkan tidak hanya mencari pekerjaan tetapi mampu menciptakan lapangan kerja sendiri.Untuk itu mahasiswa hendaknya siap dalam berwirausaha.Akan tetapi kenyataan yang penulis lihat di lapangan mahasiswa terlihat belum siap berwirausaha. Hal ini penulis simpulkan setelah menyebarkan angket kepada mahasiswa tentang keinginan mereka ketika lulus kuliah.

Sependapat dengan Darmaningtyas dalam Anggri sekar (2012: 155) menyatakan sebagai berikut.

Ada kecenderungan semakin tinggi tingkat pendidikan semakin besar keinginan mendapat pekerjaan yang aman.Mereka tidak berani mengambil pekerjaan yang beresiko seperti berwirausaha. Selain itu, rasa takut yang berlebihan akan kegagalan dan kerugian karena rasa percaya diri yang rendah menjadikan kesiapan seseorang untuk berwirausaha rendah.

Kesiapan mahasiswa untuk berwirausaha perlu diketahui.Sebab mahasiswa tidak mungkin terus mencari pekerjaan karena lowongan pekerjaan tidak seimbang dengan jumlah yang mencari pekerjaan. Ini sependapat dengan Ernawati (2018: 1) menyatakan, " Kesempatan kerja yang tersedia saat ini untuk tenaga kerja terdidik tamatan perguruan tinggi sungguh sangat tidak seimbang dengan lulusan yang dihasilkan sehingga dimana-mana terdapat pengangguran terdidik". Pernyataan ini 
didukung oleh data pengangguran lulusan perguruan tinggi yang meningkat setiap tahunnya.Data yang diperoleh dari Badan Pusat Statistik selama 3 tahun terakhir dapat dilihat pada tabel berikut.

Tabel 1. Tingkat Penggangguran Lulusan Perguruan Tinggi

\begin{tabular}{|l|l|l|}
\hline No & Tahun & Tingkat Pengangguran (\%) \\
\hline 1 & 2016 & 5.15 \\
\hline 2 & 2017 & 5.57 \\
\hline 3 & 2018 & 5.92 \\
\hline
\end{tabular}

Sumber: Badan Pusat Statistik Februari 2019

Berdasarkan uraian di atas, perlu diketahui bagaimana kesiapan mahasiswa dalam berwirausaha.Kesiapan seseorang merupakan kemampuan dirinya untuk melakukan suatu pekerjaan. Sedangkan menurut Slameto (2013 : 115) kesiapan merupakan, " Keseluruhan kondisi seseorang yang membuatnya siap untuk memberikan respon di dalam cara tertentu terhadap suatu situasi". Jadi dapat disimpulkan bahwa kesiapan adalah kondisi seseorang dimana ia mampu untuk melakukan suatu pekerjaan setelah memperoleh suatu pengalaman. Elin Anjasari (2015: 2) menyimpulkan, "Seseorang dikatakan siap membuka suatu usaha apabila sudah menyesuaikan kondisi yang ada disekitarnya". Dengan kata lain kesiapan berwirausaha adalah kemampuan seseorang yang membuatnya siap untuk melakukan suatu pekerjaan.

\section{METODE}

Jenis penelitian yang digunakan adalah penelitian deskriptif kuantitatif.Penelitian ini dilaksanakan di Jurusan Ilmu Kesejahteraan Keluarga Fakultas Pariwisata dan Perhotelan Universitas Negeri Padang. Variabel penelitian terdiri dari satu variable yakni Kesiapan Berwirausaha Mahasiswa Jurusan Ilmu Kesejahteraan Keluarga Fakultas Pariwisata Dan Perhotelan Univesitas Negeri Padang. Populasi dalam penelitian ini adalah mahasiswa S1 Tata Boga angkatan 2015 dan 2016.Teknik pengambilan sampel menggunakan teknik Proporsinal random sampling.Jenis data penelitian ini adalah data primer dan data sekunder. Teknik pengumpulan yaitu menyebarkan angket atau kuisioner dengan bantuan google form.Angket penelitian disusun menggunakan skala likert.Langkah yang dilakukan dalam analisis data ini adalah menentukan distribusi frekuensi, menentukan tingkat persentase dan teknik klasifikasi.

\section{HASIL PENELITIAN DAN PEMBAHASAN}


1. Hasil Penelitian

Berdasarkan hasil olah data dari variabel dan indikator penelitian didapat hasil sebagai berikut. Histogram pengkategorian dapat digambarkan pada gambar 1 di bawah ini:

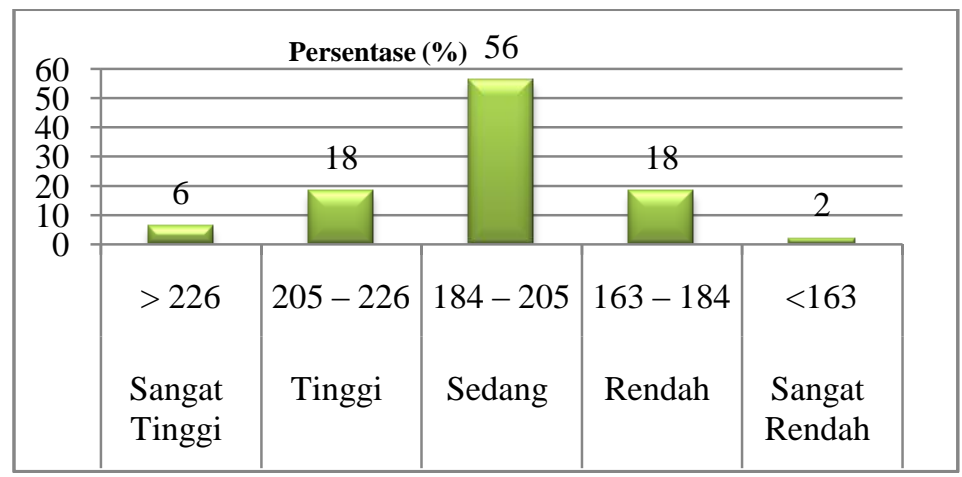

Gambar 1. Histogram Pengkategorian Kesiapan Berwirausaha Mahasiswa Secara Keseluruhan

\section{Pembahasan}

Berdasarkan hasil penelitian kepada 55 responden diketahui bahwa kesiapan berwirausaha mahasiswa secara keseluruhan berada pada kategori sedang yaitu dengan persentase 56 \% sebanyak 31 mahasiswa. Muller dalam Anggri Sekar (2012:158) mengatakan bahwa, "Kesiapan berwirausaha memiliki 3 kategori umum yang harus dimiliki yaitu, kepribadian, keterampilan, dan motivasi. Sedangkan Aulia Larasati (2018: 474) mengungkapkan bahwa pengetahuan merupakan salah satu aspek yang harus dimiliki dalam melihat kesiapan berwirausaha seseorang Dapat disimpulkan bahwa kesiapan berwirausaha adalah suatu keinginan dan kemauan yang diikuti dengan memliki kemampuan untuk siap dalam melakukan kegiatan berwirausaha, untuk melihat kesiapan berwirausaha seseorang hal penting yang harus diketahui adalah pengetahuan, keterampilan, motivasi serta kepribadian orang tersebut.

\section{a. Kepribadian}

Kesiapan Berwirausaha Mahasiswa Jurusan Ilmu Kesejahteraan Keluarga berdasarkan indikator Kepribadian memperoleh hasil persentase 51\% dengan kategori sedang. Buchari Alma (2013: 78) menyimpulkan, “ Kepribadian yang dimiliki oleh seseorang dia dapat memikat orang lain, orang menjadi simpati padanya, orang tertarik dengan pembicaraanya, orang terkesima olehnya. Wirausahawan yang memiliki kepribadian yang seperti ini seringkali berhasil dalam menjalankan usahanya".Hal ini menyatakan bahwa untuk berwirausaha diperlukan kesiapan kepribadian seseorang yang dapat dilihat dari sifat seorang wirausaha.

\section{b. Motivasi}


Kesiapan Berwirausaha Mahasiswa Jurusan Ilmu Kesejahteraan Keluarga berdasarkan indikator motivasi memperoleh hasil persentase 53\% dengan kategori sedang.Sadirman (2011:73) mengatakan, "Motivasi diartikan sebagai daya upaya yang mendorong seseorang untuk melakukan sesuatu.Motif dapat dikatakan sebagai daya penggerak dari dalam dan di dalam subjek untuk melakukan aktivitas-aktivitas tertentu demi mencapai suatu tujuan".Dengan adanya motivasi mendorong seseorang untuk melakukan suatu hal yang disukai.Sehingga motivasi diperlukan untuk mendorng kesiapan dalam berwiruasaha.

\section{c. Keterampilan}

Kesiapan Berwirausaha Mahasiswa Jurusan Ilmu Kesejahteraan Keluarga berdasarkan indikator keterampilan memperoleh hasil persentase 58\% dengan kategori sedang.Keterampilan berwirausaha menurut Suryana (2013: 80) adalah keterampilan mengonsep, keterampilan kreatif, keterampilan memimpin dan mengelola, keterampilan berkomunikasi dan berinteraksi, serta keterampilan teknik usaha.Dengan adanya keterampilan seseorang mampu untuk memperhitungkan resiko dalam berwirausaha.Seorang wirausahawan yang sukses umumnya adalah mereka yang memiliki kometensi salah satunya keterampilan.

\section{d. Pengetahuan}

Kesiapan Berwirausaha Mahasiswa Jurusan Ilmu Kesejahteraan Keluarga berdasarkan indikator pengetahuan memperoleh hasil persentase $51 \%$ dengan kategori sedang.Pengetahuan adalah ilmu yang telah diterima oleh seseorang tentang suatu hal. Pengetahuan berwirausaha menurut Suryana (2013: 81) pengetahuan usaha yang dirintis, pengetahuan lingkungan usaha, pengetahuan tentang peran dan tanggung jawab, serta pengetahuan tentang managemen bisnis. Selain itu menciptakan lapangan kerja atau berwirausaha merupakan cara menghadapai persaingan yang begitu ketat di dunia industri, hal tersebut menjadi alasan pentingnya pengatahuan tentang berwirausaha perlu dikembangkan (Nurhasanah, 2016: 3).Pengetahuan kewirausahaan inilah yang diharapkan mampu mendorong mahasiswa untuk siap dalam berwirausaha.

\section{KESIMPULAN}

Hasil penelitian menunjukan bahwa kesiapan berwirausaha mahasiswa Jurusan Ilmu Kesejahteraan Keluarga Fakultas Pariwisata dan Perhotelan UNP masih sedang. Berdasarkan hasil penelitian mengenai Kesiapan Berwirausaha Mahasiswa Jurusan Ilmu Kesejahteraan Keluarga Fakultas Pariwisata dan Perhotelan UNP termasuk dalam kategori sedang dengan indikator kepribadian, 
motivasi, keterampilan dan pengetahuan. Untuk lebih jelasnya dapat dilihat sebagai berikut.

a. Kesiapan Berwirausaha Mahasiswa Jurusan Ilmu Kesejahteraan Keluarga Fakultas Pariwisata dan Perhotelan UNP secara keseluruhan berada pada kategori sedang. Hal ini sesuai dengan latar belakang bahwa mahasiswa masih rendah dalam keinginan berwirausaha karena kesiapan untuk berwirausaha pun masih sedang.

b. Kesiapan Berwirausaha Mahasiswa Jurusan Ilmu Kesejahteraan Keluarga Fakultas Pariwisata dan Perhotelan UNP berdasarkan masing-masing Indikator yaitu indikator kepribadian, motivasi, keterampilan, dan pengetahuan memperoleh persentase yang berbeda-beda. Meski demikian keempat indikator tersebut sama-sama berada pada kategori sedang. Sehingga dapat disimpulkan bahwa kepribadian, motivasi, keterampilan, dan pengetahuan saja belum cukup untuk menumbuhkan kesiapan berwirausaha mahasiswa.

\section{SARAN}

Berdasarkan hasil penelitian yang diuraikan, maka yang menjadi saran penelitian ini adalah sebagai berikut.

a. Kepada mahasiswa diharapkan untuk meningkatkan kesiapan meraka dalam berwirausaha. Kesiapan berwirausaha dapat mereka tingkatkan dengan menambah pengetahuan dan melatih keterampilan serta menjadi pribadi yang baik dan mampu memotivasi diri sendiri. Dengan memiliki kesiapan dalam berwirausaha diharapkan mahasiswa mampu berwirausaha dan menciptakan lapangan kerja sehingga dapat mengurangi angka pengangguran.

b. Kepada Jurusan Ilmu Kesejahteraan Keluarga diharapkan untuk meningkatkan pembelajaran kepada mahasiswa terkait dengan matakuliah yang menunjang kegiatan wirausaha.

c. Kepada peneliti lain diharapkan dapat melakukan penelitian ilmiah terkait dengan hal yang berhubungan dengan kesiapan berwirausaha dengan mengkaji faktor lain yang belum peneliti bahas dalam kajian ini.

\section{DAFTAR PUSTAKA}

Anggri, Sekar Sari. 2012. “ Kesiapan Berwirausaha Pada Siswa SMK Kompetensi Keahlian Jasa Boga. Jurnal.Pendidikan Vokasi Vol.2. No 2.

Aulia, Larasati. 2018. “ Studi Eksplorasi Kesiapan Berwirausaha Mahasiswa Pendidikan IPS FIS, UNY.Jurnal. Yogyakarta.

Buchari, Alma. 2013. Kewirausahaan Untuk Mahasiswa dan Umum. Bandung: Alfabeta. 
Elin, Anjasari. 2015. "Manfaat Hasil Belajar Bisnis Makanan DietSebagai Kesiapan Membuka Usaha Katering Diet". Jurnal.Media pendidikan gizi dan kuliner vol.4 No. 1 .

Ernawati.2018. Kesiapan Mahasiswa Program Studi Tata Busana Untuk Berwirausaha Setelah Mengikuti Pilot Proyek Praktikum Mata Kuliah Usaha Busana Berbantuan Modal Pinjaman.

Nurhasanah, N., Yulastri, A., \& Fridayati, L. (2016).Potensi Berwirausaha Mahasiswa Pendidikan Tata Boga Jurusan Ilmu Kesejahteraan Keluarga Universitas Negeri Padang. E-Journal Home Economic and Tourism, 13(3).

Slameto. 2013. Belajar dan Faktor-Faktor Yang Mempengaruhinya. Jakarta: Rineka Cipta. Suryana. 2013. Kewirausahaan : Kiat dan Proses Menuju Sukses. Jakarta: Salemba Empat. 